\title{
Economic Growth of CEMAC: Does Institutional quality Matter?
}

\author{
Patrick Emmanuel Martin Seppo, PhD
}

Faculty of Social and Management Sciences, University of Buea, Cameroon

URL:http://dx.doi.org/10.19044/esj.2020.v16n7p216

\begin{abstract}
Several factors have often been noted to explain the poor performance of the CEMAC economies. In addition to the traditional factors of economic growth, institutional variables are crucial in explaining the growth of countries. This paper aimed at investigating the relationship between institutional quality and economic growth using neo-institutional theory and neoclassical theory of growth. First difference and system Generalized Method of Moments are applied on the six countries of the Central African Economic and Monetary Community for the period of 1996 to 2014. All the coefficients of the institutional variables are positive except for the quality of regulation and control of corruption. There is a positive and significant relationship between political stability and economic growth in CEMAC zone. This study recommends that political stability should be reinforced for an increase in the economic growth of the CEMAC zone.
\end{abstract}

Keywords: Institutional quality, political stability, economic growth, Generalized Method of Moment

\section{Introduction}

Institutions are a set of constraints imagined by citizens to determine their interactions, structure possibilities and ensure human exchanges. It structure incentives in human exchanges in the economic, political and social spheres (North, 1990). In this perspective, institutions are designed to ensure respect by the individual and the state for collective rules. Therefore institutions can either slow down or accelerate economic growth. Hence, the quality of institutions is very essential for production. It also determines the firm's ability to accumulate and use factors of production and ensures the optimal management of resources and the efficient and effective operation of economic activities.

Good institutions lead to returns to scale because they reduce uncertainty through coordination and control of initial costs. Indeed, they 
secure property rights (North \& Weingast, 1989; North, 1990), reduce transaction costs (North, 1990; Javaid \& Iftikhar, 2011), uncertainty (North, 1990), and the volatility of the economic environment (Klomp \& Haan, 2009; Rodrik, 1999; Acemoglu, Johnson \& Robinson, 2001).

CEMAC $^{16}$ is one of the regions of Sub-Saharan Africa that have not experienced rapid economic growth in the last two decades. Indeed, its average gross domestic product per capita is less than $5 \%$ over the period from 1996 to 2014. This weak growth is due to the low diversification of the productive base and exports of its economies, oil price shocks, weak inter-regional trade, poor quality of institutions and political instability (Abessolo, 2004; Mercereau \& Ghura, 2004; Kamgna, 2014; Diaw \& Lessoua, 2013; WGI , 2015, Besso \& Pamen, 2016).

Countries of the CEMAC zone have experienced periods of political instability. These are five coups d' Etat (1966, 1979, 1981, 2003 and 2013) and an attempted coup d' Etat (2001) in Central African Republic (CAR), five coups d' Etat $(1968,1970,1977,1979,1997)$ and two attempted coups d' Etat (1966, 1972) in Congo, four coups d' Etat $(1975,1979,1982,1990)$ and two attempted coup d' Etat $(2004,2006)$ in Chad, a coup d' Etat (1979) and an attempted coup d' Etat (2004) in Equatorial Guinea, a coup d' Etat (1964) and an attempted coup d' Etat (2019) in Gabon and an attempted coup d' Etat (1984) in Cameroon. Furthermore in Cameroon, for example, a protracted protestation of post-independence political history from April to October 1991 paralyzed economic activities in the regions of this country with the exception of those of the South, East and Centre. In addition, major unrest has also marked the period of democratic transition following the death of President Omar Bongo Ondimba in 2009 and the re-election of President Ali Bongo in 2016 in Gabon. Also, since 2013, the political context in the CEMAC zone has been marked by serious regional, political and security crises in the Central African Republic on one hand and kidnappings and terrorist attacks in the northern part of Cameroon linked to incursions of extremist groups claiming Islamist Boko Haram sect of Nigeria since 2014, on other hand.

Indeed, the CEMAC zone is one of the least rated areas by governance agencies such as Freedom House, Polity IV, Fraser Institute, Heritage Foundation, International Country Risk Guide, Freedom House and the World Bank. Actually, according to the World Bank Governance Institute (WGI, 2015), over the period from 1996 to 2014, all the averages of the indicators are negative for all countries in the CEMAC zone. In fact, scored on a scale of -2.5 to 2.5 , ie -2.5 representing institutions of worst quality and 2.5 institutions of better quality, indicators of voice and accountability and Rule of law are the

${ }^{16}$ CEMAC (Communauté économique et monétaire des États d'Afrique centrale) or Central African Economic and Monetary Community is composed of Cameroon, Congo, Central African Republic, Gabon, Equatorial Guinea and Chad. 
worst and are worth -1.16 each. That of government effectiveness is -1.14 , while the indicator of control of corruption is -1.04 , that of quality of regulation is -0.99 , and that of political stability is -075 .

However, in 1990s, the wind of democracy blowing in African countries following the collapse of the communist bloc also affects the CEMAC countries; freedom of expression, political and associative pluralism are proclaimed by the political authorities. Although, merely three decades after this majorly change, progress in governance still seems slow in the CEMAC countries, which subsequently may undermine the economic growth of this zone (World Bank 2002; IMF 2003; Yildirim \& Gökalp 2016).

According to Rodrik (1991), Alesina and Perotti (1994), political instability creates uncertainty, threatens property rights and encourages unproductive activities such as rent seeking, corruption, and discourages investment. Indeed, in periods of political instability, property rights protection mechanisms are becoming more fragile and businessmen are more inclined to reduce or reorient their investments in order to avoid risks.

Campos and Karanasos (2008) distinguish two forms of political instability, namely: the formal grouping, the number of legislative elections, the number of major constitutional changes, government crises. Second, the informal political instability manifested in non-constitutional political upheavals and social tensions between civil society and political power. In turn, Alesina et al. (1996), Siermann (1998), Fosu (2001) and Miljkovic and Rimal (2008) consider a change of government as a sign of political instability. They later define political instability as any change in executive power through legal (constitutional) forms or politically motivated (unconstitutional) violence. It is clear in their definition that normal institutional changes are considered as political instability and they also contribute to the smooth functioning of political institutions. On the other hand, other studies such as those of Alesina and Perotti (1996), Rodriguez and Rodrik (2000) and Blanco and Grier (2000) consider social unrest as political instability. As a result, their measure of political instability focused on society's response to government.

The results of studies of political instability on economic growth are mixed. Many of the studies that attempt to link political instability with economic growth have an inverse relationship (Alesina et al., 1996; Easterly \& Levine (1997; Barro, 1996; Azam, Berthelemy \& Calipel, 1996; Younis, Xiao Lin, Sharahili, \& Selvarathinam, 2008; Radu, 2015). However, another set of authors finds a weak link between political instability and economic growth (Londregan \& Poole, 1990; Levine \& Renelt, 1992).

Collier (1999) finds that, on average, a civil war usually causes a country to lose more than $2 \%$ per year of its GDP per capita compared to what it would have achieved without the war. For the World Bank (2001), political 
instability is one of the internal factors that explains the decline in economic growth on African countries since the early 1970s.

Two important studies have been done on the impact of political instability and economic performance in Chad and the Central African Republic (Abessolo, 2004; Ghura \& Mercereau, 2004). These shows that the poor performances recorded in Chad and CAR result from a particularly unstable political and social environment. Nasreen, Anwar and Waqar (2015) analyzed the long-term impact of institutions on investment and economic growth in the context of neoclassical model for the period 1985 to 2010 on 94 countries. They used cross-country and panel data techniques and their empirical results indicated that both physical and human capital investment have positive impact on economic growth. Economic freedom had a direct impact on economic growth by enhancing factor productivity and indirect by increasing investment. Political and civil liberties also exerted positive impact on investment. If we find these studies interesting, they focused on the aspect of the quality of institutions or on data coming from Freedom House reports. Their results do not provide enough information on the state of the problem in the CEMAC zone. The current paper, plans to cover the gaps in literature by studying the impact of institutional quality on economic growth in the context of neoclassical model using all the institutional variables proposed by the World Bank and on the six CEMAC countries. If we use World Governance indicators (2015) and the methodology follows by Nasreen et al. (2015) do the results differ from those obtained in (Abessolo, 2004; Ghura \& Mercereau, 2004)'s studies?

Thus, the main objective of this paper is to assess the effect of the quality of institutions in understanding growth in the CEMAC zone. This general objective is breaking into two specific objectives. While the first sub objective is to integrate the neo-institutional theory in the neo-classical theory, the second sub objective is to evaluate the role of the quality of institutions in the growth of the economies of the CEMAC zone.

Two main schools of thought are interested in empirical works on economic growth since 1950's. The first is that of neo-classical growth under the leadership of Solow (1956). The second is that of new growth theories under the direction of Romer (1986); Lucas (1988); Barro, (1989); Romer (1990); Rebelo (1991). After the deficiencies of the exogenous growth model in the explanation of steady-state economic growth at equilibrium due to his inability to explain growth with internal factors, authors like [Romer (1986); Lucas (1988); Barro, (1989); Romer (1990); Aghion \& Howitt (1992)] are interested in a new generation of models termed "endogenous growth models" to explain economic growth through proxy factors such as the accumulation of human capital, physical capital and productivity, research and development or public spending. It is in this movement that some economists have looked 
at other variables such as institutional measures among which are political instability (Barro, 1991; Ghura \& Mercereau, 2004), civil liberties and political rights ( Knack \& Keefer 1995; Scully (1989) and control of corruption (Mauro 1995; Del Monte \& Papagni 2001).

Mankiw, Romer and Weil (1992) and Islam (1995) enriched the neoclassical growth model by integrating human capital. Unlike Mankiw et al. (1992) who use cross-sectional data, Islam (1995) uses panel data. Mankiw et al., (1992) and Islam (1995) do not value technology in their work. This is part of the error term in their analyses. Nevertheless, they consider that the initial technology can be represented by resource endowments, climate, economic policies or the quality of institutions that may differ from one country to another. Mankiw et al. (1992) also hope that differences in tax, education, children's tastes and political stability are among the ultimate determinants of the difference in income between countries. In Mankiw et al. (1992), the term $A$ represents technology or other variables such as resource endowments, climate and institutions, and other factors that may affect factor productivity. Since the quality of institutions affects productivity, the present work assumes that term $A$ depends on the quality of institutions.

The rest of the paper is organized as follows; Section 1 presents the literature review; data and model specification appear in section 2; section 3 presents the estimation technique, section 4 discusses estimation results; conclusion and policy implications of the study appear in section 5 .

\section{Literature Review}

After a decade of 1980 considered as a "lost decade" for most economies, the early 1990s for economists was a time of hope for economies around the world. At the same time, reforms following the Washington consensus led not only to poverty reduction, rapid growth, but also social progress in Latin America and East Asia. By contrast, sub-Saharan Africa has not experienced the same change (World Bank 2005; Rodrik 1999). To reduce poverty and obtain rapid growth in sub-Saharan Africa, large sums have been allocated to African countries through official development assistance and reforms initiated. But poverty still reigns in Africa, and the gap between rich and poor countries continues to widen. However, Rodrik (1999; 2003) and World Bank (2005) draw attention to the need for catching up in other parts of the world. Knack and Keefer (1995) argue that the reforms undertaken in the 1990s have not produced good results because of an unfavourable institutional environment characterized by insecure property rights and low level of rule of law. According to Rodrik (1996), the difficulties encountered in implementing these reforms are the cause of the backwardness of countries that have not experienced a take-off after these reforms. This author shows that, beyond external shocks, latent social conflicts, conflict management 
institutions are responsible for the failures of the reforms initiated as a result of the Washington Consensus.

In the absence of an appropriate institutional framework where the rule of law prevails, political stability, property rights are well executed, and corruption is under control, infrastructure development projects, public and private investment cannot function well in Third World countries (Easterly, 2001). Although several works (Acemoglu, Johnson \& Robinson, 2001; 2002; Rodrik, Subramanian \& Trebbi, 2004) have dwelt on the importance of institutions in explaining economic growth, Glaeser, La Porta, Lopez-deSilanes \& Shleifer (2004) criticized its relevance and showed that human capital was the most robust determinant. They latter reviewed the debate on the impact of political institutions on growth on one hand, and the impact of economic growth and human capital accumulation on institutional development on the other hand. For these authors, poor countries will have to put better policies in place and improve their political institutions afterwards.

Fabro and Aixalá (2009) studied the link between economic growth and quality of institutions by applying the generalized system moments method, the double and triple least squares in a sample of 145 countries. They find out that the direct impact of the quality of institutions on the per capita GDP of countries is a function of the level of development of the country concerned. For these authors, this impact is positive but not significant for countries with very low per capita income, and is more positive and significant for middle-income countries than for rich countries.

Dawson (1998) specified his models as a multiple regression model on one hand, and as a panel data model on the other hand. He added institutions to the traditional factors of the neoclassical model. From a sample of 85 countries and from 1975 to 1990, the author finds that the introduction of economic freedom as a factor in the Mankiw et al. (1992) increases $\mathrm{R}^{2}$ from 0.29 to 0.47 . His results show that economic freedom has a significant and positive impact on economic growth. But, the author finds that civil and political freedoms do not have a significant impact on economic growth.

Kilishi, Mobalaji, Yaru and Yakubu (2013) studied the impact of institutions on the poor economic performance of 36 countries in sub-Saharan Africa over the period 1996 to 2010. The authors use the 6 governance indicators of the World Bank: voice and accountability, political stability, quality of regulation, rule of law and control of corruption and aggregate indicator of the 6 indicators above, and interaction effects between variables representing the quality of institutions and the commercial opening. They specify a Solow model enriched to institutions in the form of a dynamic panel model. The authors find that the coefficients of investment in physical and human capital are positive and significant. The coefficient of the growth rate 
of the population is significant and negative. Of the six governance indicators, only the coefficients of regulation quality and the rule of law were significant.

In turn, Avom and Song (2014) examined the effects of institutions and human capital on economic growth in sub-Saharan Africa during the period 2000-2010. The authors use a fixed-effects panel data model in which they adopt Rodrik's (2005) classification approach for economic institutions by distinguishing market-creating institutions, market stabilization institutions, regulators market and market legitimation institutions. Using the variables of Polity IV, Economic Freedom and World Development Indicators, the authors found that market creation, regulatory stabilization and human capital institutions stimulate economic growth for the sample in question. On the other hand, legitimating institutions deteriorate economic growth.

In their works, Abessolo (2004) and Ghura and Mercereau (2004) showed that the poor performances recorded by Chad and the CAR respectively result from a particularly unstable political and social environment. In the same vein, Fondo and Teke (1992) showed that improving governance will lead to stronger economic growth in Cameroon.

\section{Model specification and data}

The model used in this study is an augmented neoclassical model (Solow, 1956) inspired by the empirical studies of [Mankiw et al., (1992); Dawson (1998); Islam (1995)]. It is a Cobb-Douglas equation with Harrodneutral technical progress and decreasing efficiency. Where $\alpha$ and $\beta$ are the elasticities of production in relation to physical and human capital, respectively. $Y$ is the level of production, $K$ and $H$ are the physical and human capital respectively. $L$ is labour force and $A$ is the level of technology. (1- $\alpha-\beta)$ is the income elasticity per effective work unit. Assuming that labour force has an exogenous growth rate, $n$, the exogenous technical progress increases at the rate $g$, in such a way that $L(t)=L(0) e^{n t}$ and $A(t)=A(0) e^{g t}$. Physical and human capital depreciate at the same rate $\delta . S^{k}$ and $S^{h}$ are proportions of income invested in physical and human capital respectively. $n$ represent active population, $q$ institutional quality. The income equation for CEMAC countries is:

$$
\begin{aligned}
& \ln y_{i}\left(t_{2}\right)-\ln y_{i}\left(t_{1}\right)=\left(1-e^{-\lambda \tau}\right) \frac{\alpha}{1-\alpha} \ln \left(S^{k}\right)_{i t}+\left(1-e^{-\lambda \tau}\right) \frac{\beta}{1-\alpha} \ln \left(S^{h}\right)_{i t}-\left(1-e^{-\lambda \tau}\right) \frac{\alpha}{1-\alpha} \ln \left(n_{i t}+g+\delta\right) \\
& -\left(1-e^{-\lambda \tau}\right) \ln y_{i}\left(t_{1}\right)+\left(1-e^{-\lambda \tau}\right) \ln A(0)_{i t}+\left(1-e^{-\lambda \tau}\right) \mu \ln q_{i t}+g\left(t_{2}-e^{-\lambda \tau}\left(t_{1}\right)\right)+v_{i t}
\end{aligned}
$$

Equation (1) above can be written as follows: 
$y_{i t}=\gamma y_{i, t-1}+\sum_{j}^{4} \beta_{j} x_{i t}^{j}+\eta_{t}+\mu_{i}+v_{i t}$

where $y_{i t}=\ln y_{i}(t), y_{i, t-1}=\ln y_{i}(t-1), \gamma=e^{-\lambda \tau}, \beta_{1}=\left(1-e^{-\lambda \tau}\right) \frac{\alpha}{1-\alpha}, \quad \beta_{2}=\left(1-e^{-\lambda \tau}\right) \frac{\alpha}{1-\alpha}$

$\beta_{3}=\left(1-e^{-\lambda \tau}\right) \frac{\beta}{1-\alpha}, \beta_{4}=\left(1-e^{-\lambda \tau}\right) \mu \quad x_{i t}^{1}=\ln \left(S_{i t}^{k}\right), x_{i t}^{2}=\ln \left(S_{i t}^{k}\right) x_{i t}^{3}=\ln \left(n_{i t}+g+\delta\right)$

$x_{i t}^{4}=\ln \left(q_{i t}\right), \mu_{i}=\left(1-e^{-\lambda \tau}\right) \ln A(0), n_{i t}=g\left(t_{2}-e^{-\lambda \tau}\left(t_{1}\right)\right)$

This study employs panel data analysis because our objective is to estimate long term relationship between institutional quality and economic growth. Moreover, panel data can control country specific effects and also assume different production functions for different countries while cross-section data assume same production function for all countries. For panel data analysis, equation to be estimated can be written in the following form:

$$
y_{i, t}=\gamma y_{i, t-1}+\phi q_{i, t}+\beta X_{i t}{ }^{\prime}+\eta_{i}+\varepsilon_{i t}
$$

$\mathrm{y}_{\mathrm{i}, \mathrm{t}}$ is $\ln$ of GDP per capita in countries $i$ at time $t, \mathrm{y}_{\mathrm{i}, \mathrm{t}-1}$ is lagged variable of GDP per capita. $q$ refers to institutional quality that is approximated by control of corruption, rule of law, voice and accountability, quality of regulation, government effectiveness and rule of law. The data used in this study (see table 1 in appendix) are annual data from 1996 to 2014, covering the six countries in the CEMAC zone: Cameroon, Congo, Central African Republic, Gabon, Equatorial Guinea and Chad. The choice of annual data in this work is largely motivated by the independent variable of interest: the quality of institutions whose data comes from the World Bank Governance Institute (2015). Apparently, the average data are better when looking at the long-term link between economic growth and the quality of institutions. Nevertheless, the generalized moment's method produces relatively interesting results for a panel of several countries and few years (Roodman, 2009). Studies of generalized moment's method in system invariably use average data while ensuring that the number of countries is greater than the number of years. In the case of this work, the number $N=6$ countries is less than the number of years 19 , and the quality of the results could be reduced. It is necessary to carry out an analysis for the case of the countries of the CEMAC zone which are of low institutional quality. The data used in this work are secondary data and comes from two sources namely: World Development Indicators (2015) and 
World Governance Indicators (2015). Economic growth is measured in terms of GDP per capita. $X_{i t}^{\prime}$ is a vector of control variables; Physical capital is measured by gross fixed capital formation. Human capital is measured by the number of students enrolled in secondary education. The labor force is measured by the rate of growth of the population, $n$. Like Mankiw et al. (1992), we assumed that $n+g=0.05$.

We use World Bank governance indicators. However, since the data were bi-annual from 1996 to 2002, we applied linear interpolation for the years 1997, 1999 and 2001. The worldwide Governance indicators are aggregate indicators of six broad dimensions of governance namely: Voice and Accountability, Political Stability and Absence of violence and Terrorism, Government Effectiveness, Regulatory Quality, Rule of Law and Control of Corruption. The six indicators are based on 30 underlying data sources reporting the perceptions of a large number of survey respondents and expert assessment worldwide.

Voice and Accountability reflects the perception of the extent to which citizens of a given country are able to participate in the selection of their government, as well as freedom of association, freedom of expression and freedom of Press. Political stability and the absence of violence reflect the perception of the likelihood that the current government will be destabilized by unconstitutional or violent means, including terrorism. Government Effectiveness reflects the perception this indicator provides information of the quality of public services, the quality of the public service and its independence from political pressures and the quality of the formulation and the implementation and the credibility of the government's commitment. Regulatory Quality reflects the perception of the ability of the government to provide sound policies and sound regulations that enable and promote private sector development. The Rule of Law reflects the perception of the extent to which different agents trust and respect company rules that include the quality of contract enforcement, property rights, the police and courts and the likelihood of crime and violence. The control of corruption reflects the extent to which the public power is exercised for private purposes. It encompasses all forms of corruption, including large and small forms of corruption, as well as the capture of the state by the elite and private interests.

Governance indicators are rated on a scale of -2.5 to 2.5 , with -2.5 representing institutions of worse quality and 2.5 better institutions. The indicators have been transformed so that the transformed indicators take values from 1 to 6 . The transformed governance indicators are such that low values correspond to poor governance and high values correspond to better governance. $\eta_{i}$ is country fixed effects and $\varepsilon_{i t}$ is the error term. Table 2 below shows descriptive statistics. 
Table 2: Descriptive Statistics

\begin{tabular}{|l|c|c|c|c|c|}
\hline \multicolumn{1}{|c|}{} & $\begin{array}{c}\text { Number of } \\
\text { variables }\end{array}$ & Mean & $\begin{array}{c}\text { Standard } \\
\text { deviation }\end{array}$ & Minimum & Maximum \\
\hline $\begin{array}{l}\text { GDP Per Capita } \\
\text { Gross fixed } \\
\text { capital formation }\end{array}$ & 144 & $3,631,013$ & $5,473,581$ & 166,008 & $233,47.66$ \\
\hline $\begin{array}{l}\text { Secondary school } \\
\text { enrollment rate }\end{array}$ & 144 & $28,595.13$ & 14.296 & 8.464 & 56,43073 \\
\hline Population & 144 & $2,730,853$ & 0.545 & 1,683 & $3,882,788$ \\
\hline $\begin{array}{l}\text { Voice and } \\
\text { Accountability }\end{array}$ & 144 & 2.33 & 0.36 & 1.52 & 3.18 \\
\hline Political Stability & 144 & 2.75 & 0.77 & 0.83 & 4 \\
\hline $\begin{array}{l}\text { Quality of } \\
\text { Regulation }\end{array}$ & 144 & 2.51 & 0.4 & 1.78 & 3.64 \\
\hline $\begin{array}{l}\text { Gouvernement } \\
\text { Effectiveness }\end{array}$ & 144 & 2.36 & 0.36 & 1.66 & 3.16 \\
\hline $\begin{array}{l}\text { Rule of Law } \\
\text { Control of } \\
\text { Corruption }\end{array}$ & 144 & 2.34 & 0.365 & 1.66 & 3.34 \\
\hline
\end{tabular}

Source: WDI (2015), WBGI (2015) and author's calculus

Over the period of the study (1996-2014), the average GDP per capita of the CEMAC zone amounts to US \$33,631,013. The standard deviation of CEMAC's GDP per capita is US $\$ 5,473,581$. This means that most GDP per capita values differ from the average per capita GDP of US $\$ 5,473,581$. The lowest GDP per capita of the zone amounts to 166, 008 US dollars while the highest is worth 233, 47.66 US dollars.

At the same time, the lowest indicator of voice and accountability in the area is 2.3. Its standard deviation is 0.36 . This means that most of the values of the voice and accountability indicator of the zone differ from the mean of the indicator voice and accountability of 0.36 . The lowest level reached by this indicator is 1.52 while its best score is 3.18.

Similarly, the average political stability indicator for the CEMAC zone is 2.75. This shows the unstable nature of the political stability of the CEMAC zone. Its standard deviation is 0.77 . This means that most values of the CEMAC indicator of political stability differ from its average of 0.77 . Its best score is 4.00 when its worst score is 0.83 . 
Table 3 below presents the correlation matrix whose purpose is to measure the degree of correlation between the coefficients of the variables. It also shows the degree of linear relationship between the variables. This matrix shows the degree of correlation between the independent variables of the model and justifies the empirical relationship between GDP per capita and the independent variables. The diagonal of the correlation matrix shows the degree of association between a variable and itself.

The correlation coefficients 0.62 and 0.25 shows a weak positive correlation between political stability, the rule of law and GDP per capita. Also, the correlation coefficients $-0.41,-0.3,-0.05,-0.17$ show a weak and negative link between the indicators of voice and accountability, the rule of law, quality of regulation, the government effectiveness, the control of corruption, and the gross domestic product per capita.

\begin{tabular}{|c|c|c|c|c|c|c|c|c|c|c|}
\hline & $\begin{array}{l}\text { GDP per } \\
\text { capita }\end{array}$ & $\begin{array}{c}\text { Physical } \\
\text { capital }\end{array}$ & $\begin{array}{l}\text { Human } \\
\text { capital }\end{array}$ & $\begin{array}{c}\text { Active } \\
\text { Population }\end{array}$ & $\begin{array}{c}\text { Voice and } \\
\text { Accountability }\end{array}$ & $\begin{array}{c}\text { Political Stability and } \\
\text { Absence of violence } \\
\text { and Terrorism }\end{array}$ & $\begin{array}{l}\text { Gouvernement } \\
\text { Effectiveness }\end{array}$ & $\begin{array}{c}\text { Regulatory } \\
\text { Qualiy }\end{array}$ & $\begin{array}{l}\text { Rule of } \\
\text { Law }\end{array}$ & $\begin{array}{l}\text { Control of } \\
\text { Corruption }\end{array}$ \\
\hline GDP per capita & 1 & & & & & & & & & \\
\hline Physical capital & 0.14 & 1 & & & & & & & & \\
\hline Human capital & 0.273 & 0.020 & 1 & & & & & & & \\
\hline Active Population & 0.066 & 0.48 & -0.020 & 1 & & & & & & \\
\hline $\begin{array}{l}\text { Voice and } \\
\text { Accountability }\end{array}$ & -0.412 & -0.44 & 0.26 & -0.44 & 1 & & & & & \\
\hline $\begin{array}{l}\text { Political Stability and } \\
\text { Absence of violence and } \\
\text { Terrorism }\end{array}$ & 0.620 & 0.311 & 0.6223 & 0.44 & 0.05 & 1 & & & & \\
\hline $\begin{array}{l}\text { Government } \\
\text { Effectiveness }\end{array}$ & -0.167 & -0.19 & 0.45 & 0.035 & 0.7 & 0.41 & 1 & & & \\
\hline Regulatory Quality & -0.05 & -0.43 & 0.41 & -0.04 & 0.78 & 0.34 & 0.78 & 1 & & \\
\hline Rule of Law & 0.24 & -0.07 & 0.63 & -0.2 & 0.61 & 0.68 & 0.75 & 0.77 & 1 & \\
\hline Control of Corruption & -0.3 & -0.35 & 0.4 & -0.17 & 0.79 & 0.1 & 0.65 & 0.68 & 0.65 & 1 \\
\hline
\end{tabular}




\section{Estimation Technique: The Generalized Method of Moments}

Practically, the estimation of our model poses two main problems: endogeneity of variables and double causality. To correct these problems, we adopt the generalized method of moments with instrumentalization of the variables. Indeed, Arrellano and Bond (1991) and Arrellano and Bover (1995) constructed unbiased estimators, convergent and asymptotically distributed. They show that the problem endogeneity comes either from a strong relationship between the dependent variable and some independent variables; either of a multicollinearity between the explanatory variables. Blundell and Bond (1998) tested this method at using Monte Carlo simulations. These authors find that the estimator of generalized moments in system is more efficient than that in first difference which exploits only the conditions of the moments of the equation in primary difference with delayed variables as instruments in level (Arellano \& Bond, 1991). To solve the problem of the nature of instruments, it makes sense to introduce variables that have nothing in common such as institutional or geographic variables (distance) or delay some or all of the explanatory variables and test their validity by a test of Sargan or Hansen (Roodman, 2009).

The estimation of the Augmented Islam model by Generalized Moment Method in first difference and System is presented in table 4 below. 
Table 4: Estimation of the Augmented Islam model by GMM in first difference and System

\begin{tabular}{|c|c|c|c|c|c|c|c|c|c|c|c|c|c|c|}
\hline \multicolumn{15}{|c|}{ Dependent Variable: Gross Domestic Product per capita } \\
\hline & DIF & SYS & DIF & SYS & DIF & SYS & DIF & SYS & DIF & SYS & DIF & SYS & DIF & SYS \\
\hline GDP per capitat $t_{t-1}$ & $\begin{array}{l}-0.13^{* * *} \\
(0.0514)\end{array}$ & $\begin{array}{c}-0.04^{* * *} \\
(0.04)\end{array}$ & $\begin{array}{c}-0.193^{* * * *} \\
(0.04)\end{array}$ & $\begin{array}{c}-0.077^{* * * *} \\
(0.021)\end{array}$ & $\begin{array}{c}-0.203^{* * * *} \\
(0.04)\end{array}$ & $\begin{array}{c}-0.051^{* * * *} \\
(0.200)\end{array}$ & $\begin{array}{c}-0.170^{* * * *} \\
(0.04)\end{array}$ & $\begin{array}{c}-0.05^{* *} \\
(0.02)\end{array}$ & $\begin{array}{c}-0.186^{* * * *} \\
0.04\end{array}$ & $\begin{array}{c}-0.052^{* * * *} \\
(0.02)\end{array}$ & $\begin{array}{l}-0.2^{* * * *} \\
(0.041)\end{array}$ & $\begin{array}{c}-0.07^{* * * *} \\
(0.22)\end{array}$ & $\begin{array}{c}-0.16 \text { **** } \\
(0.04)\end{array}$ & $\begin{array}{l}-0.041^{* *} \\
(0,021)\end{array}$ \\
\hline Physical Capital & $\begin{array}{l}-0.246^{* * *} \\
(0.081)\end{array}$ & $\begin{array}{l}-0.02 \\
0.056\end{array}$ & $\begin{array}{c}-0.216^{* * *} \\
(0.083)\end{array}$ & $\begin{array}{l}-0.027 \\
(0.053)\end{array}$ & $\begin{array}{c}-0.196^{* * *} \\
(0.08)\end{array}$ & $\begin{array}{l}-0.02 \\
0.055\end{array}$ & $\begin{array}{c}-0.224^{* * * *} \\
(0.086)\end{array}$ & $\begin{array}{l}-0.021 \\
(0.055)\end{array}$ & $\begin{array}{c}-0.243^{* * *} \\
0.088\end{array}$ & $\begin{array}{c}-0.02 \\
(0.057)\end{array}$ & $\begin{array}{l}-0.183^{* *} \\
(0.803)\end{array}$ & $\begin{array}{l}-0.002 \\
(0.05)\end{array}$ & $\begin{array}{r}-0.265 \\
(0.09)\end{array}$ & $\begin{array}{l}-0.041 \\
(0.057)\end{array}$ \\
\hline Human Capital & $\begin{array}{l}0.031 \\
(0.010)\end{array}$ & $\begin{array}{l}0.056 \\
(0.06)\end{array}$ & $\begin{array}{c}0.078 \\
(0.108)\end{array}$ & $\begin{array}{c}0.045 \\
(0.053)\end{array}$ & $\begin{array}{c}0.031 \\
(0.101)\end{array}$ & $\begin{array}{c}0.084 \\
(0.056)\end{array}$ & $\begin{array}{c}0.04 \\
(0.103)\end{array}$ & $\begin{array}{c}0.065 \\
(0.635)\end{array}$ & $\begin{array}{l}0.0505 \\
(0.102)\end{array}$ & $\begin{array}{c}0.065 \\
(0.057)\end{array}$ & $\begin{array}{c}0.054 \\
(0.103)\end{array}$ & $\begin{array}{c}0.14 \\
(0.06)\end{array}$ & $\begin{array}{l}0,045 \\
(0.10)\end{array}$ & $\begin{array}{c}0.04 \\
(0.059)\end{array}$ \\
\hline Active Population & $\begin{array}{c}0.57 \\
0.544\end{array}$ & $\begin{array}{l}0.375^{*} \\
(0.14)\end{array}$ & $\begin{array}{l}0.764 \\
(0.58)\end{array}$ & $\begin{array}{c}0.344^{* * *} \\
(0.132)\end{array}$ & $\begin{array}{c}0.4 \\
(0.51)\end{array}$ & $\begin{array}{c}0.34^{* * *} \\
0.132\end{array}$ & $\begin{array}{c}0.375 \\
(0.538)\end{array}$ & $\begin{array}{c}0.366^{* * *} \\
(0.134)\end{array}$ & $\begin{array}{c}0.580 \\
(0.538)\end{array}$ & $\begin{array}{c}0.366^{* * *} \\
(0.138)\end{array}$ & $\begin{array}{c}0.374 \\
(0.533)\end{array}$ & $\begin{array}{c}0.24 \\
(0.14)\end{array}$ & $\begin{array}{l}0.326 \\
(0.53)\end{array}$ & $\begin{array}{l}0.222 \\
(0.14)\end{array}$ \\
\hline Voice and Accountability & $\begin{array}{c}0.573 \\
(0.398)\end{array}$ & $\begin{array}{l}0.130 \\
(0.18)\end{array}$ & & & & & & & & & & & & \\
\hline Political Stability & & & $\begin{array}{l}0.196^{*} \\
(0.14)\end{array}$ & $\begin{array}{c}0.194^{* * *} \\
0.080\end{array}$ & & & & & & & & & & \\
\hline Quality of Regulation & & & & & $\begin{array}{l}-0.522 \\
(0.41)\end{array}$ & $\begin{array}{c}-0.072 \\
0.172\end{array}$ & & & & & & & & \\
\hline Government Effectiveness & & & & & & & $\begin{array}{l}0.337 \\
(0.34)\end{array}$ & $\begin{array}{l}-0.127 \\
(0.172)\end{array}$ & & & & & & \\
\hline Rule of Law & & & & & & & & & $\begin{array}{c}0.388 \\
(0.302)\end{array}$ & $\begin{array}{c}0.14 \\
(0.16)\end{array}$ & & & & \\
\hline Control of corruption & & & & & & & & & & & $\begin{array}{c}-0.286 \\
(0.3)\end{array}$ & $\begin{array}{l}-0.25 \\
(0.20)\end{array}$ & & \\
\hline Constant & & $\begin{array}{l}-0,19 \\
(0.22)\end{array}$ & & $\begin{array}{l}0.1946 \\
0.0802\end{array}$ & & $\begin{array}{l}-0.005 \\
(0.203)\end{array}$ & & $\begin{array}{l}-0.127 \\
(0.163)\end{array}$ & & $\begin{array}{l}-0.145 \\
(0.164)\end{array}$ & & $\begin{array}{l}0.142 \\
(0.25)\end{array}$ & & $\begin{array}{l}0.074 \\
(0.2)\end{array}$ \\
\hline $\begin{array}{l}\text { Number of observations } \\
A R(1)\end{array}$ & 72 & 78 & 72 & 78 & 72 & 78 & 72 & 78 & 72 & 78 & 76 & 78 & 72 & 78 \\
\hline Probability value & $(0.001)$ & $(0.00)$ & $(0.001)$ & $(0.001)$ & $(0.002)$ & $(0.001)$ & $(0.001)$ & $(0.001)$ & $(0.002)$ & $(0.01)$ & $(0.001)$ & $(0.00)$ & $(0.00)$ & $(0.001)$ \\
\hline $\begin{array}{l}\text { AR }(2) \\
\text { Probability value }\end{array}$ & $(0.143)$ & $(0.14)$ & $(0.153)$ & $(0.145)$ & $(0.146)$ & $(0.143)$ & $(0.163)$ & $(0.145)$ & $(0.160)$ & $(0.144)$ & $(0.176)$ & $(0.17)$ & $(0.15)$ & $(0,142)$ \\
\hline $\begin{array}{l}\text { Sargan's statistics } \\
\text { Probability of Sargan }\end{array}$ & $\begin{array}{l}65.07 \\
(0.544)\end{array}$ & $\begin{array}{l}152.87 \\
(0.11)\end{array}$ & $\begin{array}{c}64.28 \\
(0.572)\end{array}$ & $\begin{array}{l}147.86 \\
(0.179)\end{array}$ & $\begin{array}{c}67.78 \\
(0.450)\end{array}$ & $\begin{array}{l}155.60 \\
(0.088)\end{array}$ & $\begin{array}{c}66.48 \\
(0.495)\end{array}$ & $\begin{array}{l}151.25 \\
(0.133)\end{array}$ & $\begin{array}{c}68.26 \\
(0.434)\end{array}$ & $\begin{array}{l}154.07 \\
(0.102)\end{array}$ & $\begin{array}{c}67.85 \\
(0.448)\end{array}$ & $\begin{array}{c}152.33 \\
(0.12)\end{array}$ & $\begin{array}{l}66.71 \\
(0.49)\end{array}$ & $\begin{array}{l}153.25 \\
(0.110)\end{array}$ \\
\hline Implicit Alpha & 25.56 & 19.96 & 20.41 & 32.7 & 19.83 & 38.06 & 22.04 & 40.66 & 20.87 & 37.41 & 19.96 & 33.63 & 22.82 & 40.66 \\
\hline Convergence speed & 2.04 & 1.61 & 1.65 & 2.56 & 1.6 & 3 & 1.77 & 3.2 & 1.68 & 2.95 & 1.61 & 2.66 & 1.83 & 3.2 \\
\hline
\end{tabular}

Notes: *,***** represent significance level at $10 \%, 5 \%$, and $1 \%$ respectively

Numbers in parentheses represent the standard deviations of the estimated coefficients.

SYS corresponds to the estimation obtained using System GMM DIF corresponds to estimation obtained using first difference GMM

Source: Author 


\section{Estimation results}

The estimation results are represented in table 4 above. We first estimate the model using difference GMM. In the case of the voice and accountability model, for example, the coefficient of GDP per capita initially delayed by one year is -0.134 and is significant at $1 \%$. This coefficient is negative and between -0.13 and -0.23 and is significant at $1 \%$ for all models. The $\beta$-convergence hypothesis is therefore validated for this study period.

The coefficient of physical capital is negative in all models. But, it is significant at $1 \%$ for models with voice and accountability, political stability, efficiency of public authorities, regulatory quality and the rule of law. And this same coefficient is significant at $5 \%$ for the model with the control of the corruption. This result means that physical capital negatively impacts economic growth. This can be justified by the low quantity and quality of physical capital in the CEMAC zone.

The coefficient of human capital is positive, but not significant on all models. Human capital has no effect on economic growth. This result can be justified from the variable chosen to approximate the human capital, namely the secondary school enrolment rate. The choice of this variable is imposed by the readily available database which is that of the World Bank's development indicators. The construction of other proxies of human capital in the CEMAC countries may give different results on the relationship between human capital and economic growth.

Then the population coefficient is positive but not significant in all models. This result means that the population does not impact growth.

Most of the coefficients of the institutional variables are positive, but not significant. The coefficient of political stability is significant at $10 \%$ and is worth 0.196 . On the other hand, the coefficients of the models relating to the control of the corruption and the quality of the regulation have negative coefficients. This result shows that political stability is of paramount importance to stimulate economic growth in the CEMAC zone. An improvement in the $1 \%$ political stability indicator in this zone will lead to a growth increase of $0.2 \%$ of economic growth of the CEMAC region.

Arellano and Bond's first-order autocorrelation test, AR (1), makes it possible to reject the first-order negative correlation of residues. For its part, the second-order autocorrelation test by Arellano and Bond, AR (2), does not make it possible to reject the hypothesis of the absence of second-order autocorrelation of the residues. Finally, the Sargan test makes it possible to reject the hypothesis of the validity of the lagged variable of GDP per capita as an instrument and validates the specified model.

In order to take into account the potential endogeneity of the GDP per capita and the weakness of the instruments due to the estimation by the 
generalized method of moment in first difference, we apply the estimator of the generalized moments in system proposed by Blundell and Bond (1998).

The $\beta$-convergence hypothesis is validated for the study period for models with political stability, quality of regulation, rule of law and control of corruption. In the following, the coefficient of physical capital is negative and not significant in all models. This result means that physical capital does not impact economic growth. The quality and quantity of physical capital does not seem sufficient to increase private investment and economic growth in the CEMAC countries.

The coefficient of human capital is positive, but not significant on all models. Human capital has no effect on economic growth. This result would come from the variable chosen to approximate the human capital, namely the secondary school enrolment rate. This indicator is increasingly challenged in new work in favour of the number of completed years of study or the quality of education.

The coefficient of population is positive in all models. This is significant at $1 \%$ in models with political stability, government effectiveness, and control of corruption. This coefficient is significant at $10 \%$ in the model with representation and participation. Lastly, it is not significant for the model dealing with the control of corruption.

All the coefficients of the institutional variables are positive except for the quality of regulation and control of corruption. Only political stability's coefficient is significant. It is significant at $1 \%$ and is worth 0.2 . The other coefficients of the institutional variables are not significant. This shows that political stability impacts economic growth. Indeed a unit point increase in the indicator of political stability in this zone would increase economic growth by almost 0.2 percentage points.

Arellano and Bond's first-order autocorrelation test, AR (1) makes it possible to reject the first-order negative correlation of residues. The secondorder autocorrelation test by Arellano and Bond, AR (2) does not reject the hypothesis of no second-order autocorrelation of residues. Finally, the Sargan test makes it possible to reject the hypothesis of the validity of the lagged variable of GDP per capita as an instrument and validates the specified model. These results confirm those obtained by Fabro and Aixalá (2009) for whom the coefficient of the aggregate governance indicator is insignificant, but positive for countries with very low income per capita. On the other hand, these results contradict those of Kilishi et al. (2013) in which the coefficients of the quality of regulation and the rule of law are significant and positive.

\section{Conclusion and policy implications}

This study investigates the relationship between institutional quality and economic growth using neo-institutional theory and neoclassical theory of 
growth. Generalized Method of Moment technique is applied on the six countries of CEMAC for the period 1996 to 2014. Physical capital and human capital are important factors in understanding the growth of the six CEMAC countries. There is a positive and significant relationship between political stability and economic growth in CEMAC zone. This relationship is more significant with system generalized method of moment estimator than first difference method moment estimator. The likelihood that an incumbent government will be destabilized by unconstitutional or violent means, including terrorism has positively impacted the economic growth of the area. Political instability in CAR and Chad appears to have negatively affected economic growth in this area. But, they were politically unstable because of low economic viability. Also, the mode of elections of members of the executive power, the ability of political parties to win an election or freedom of association, freedom of expression and belief have a positive effect on economic growth. These results also shows that the measures taken by the member countries of the zone to guarantee political stability are beneficial for the economic growth of the CEMAC zone.

\section{References:}

1. Abessolo, Y. (2004). Instabilité Politique Et performances Economiques: une évaluation du cas du Tchad. Retrieved from https: //harribey.u-bordeaux4.fr/colloques/abessolo.pdf

2. Acemoglu, D., Johnson, S., \& Robinson, J. (2001). The Colonial Origin of Comparative Development: An empirical investigation. American Economic Review, 91(5), 1369-1401.

3. Aghion, P., \& Howitt, P. (1992). A model of growth through creative destruction. Econometrica, 60(2), 323-351.

4. Alesina, A., Devleeschauwer, A., Easterly, W., Kurlat, S., \& Wacziarg, R. (2003). Fractionalization. (NBER Working Paper No. 9411). Cambridge, MA, National Bureau of Economic Research.

5. Alesina, A., \& Perotti, R. (1996). Income distribution, political instability and investment. European Economic Review, 40, 12031228.

6. Alesina, A., Ozler, S., Roubini, N., \& Swagel, P. (1996). Political instability and economic growth. Journal of Economic Growth, 1, 189211.

7. Arellano, M., \& Bond. S. R. (1991). Some Tests of Specification for Panel data: Monte Carlo Evidence and an Application to Employment Equations. Review of Economics Studies, 58(2), 277-297.

8. Arellano, M., \& Bover, O. (1995). Another Look at the InstrumentalVariable Estimation of Error-Components Models. Journal of Econometrics, 68, 29-52. 
9. Avom, D., \& Song J. S. (2014). Institutions économiques, capital humain et croissance économique en Afrique au Sud du Sahara.www.ecoasso.org/articles/Song_et_Avom.pdf

10. Azam, J-P., Berthelemy, J-C., \& Calipel, S. (1996). Risque politique et croissance en Afrique. Revue économique, 47(3), Développements récents de l'analyse économique: XLIVe congrès annuel de l'Association française de science économique 1995, 819-829.

11. Banque Mondiale (2001). Rapport sur le Développement 2000-2001, Washington.

12. Barro, R. J. (1996). Democracy and Growth. Journal of Economic Growth, 1(1), 1-27.

13. Barro, R. J. (1991). Economic Growth in a Cross Section of Countries. The Quarterly Journal of Economics, 106(2), 407-443.

14. Besso, R. C., \& Feubi, P. P. E. (2016). Oil price shock and economic growth: Experience of CEMAC countries. https://mpra.ub.unimuenchen.de/76034/MPRA Paper No. 76034

15. Blanco, L., \& Grier, R. (2009). Long live democracy: The determinants of political instability in Latin America. The Journal of Development Studies, 45, 76-95.

16. Blundell, R., \& Bond, S. (1998). Initial Conditions and Moments Restrictions in Dynamic Panel Data Models. Journal of Econometrics, 87, 115-143.

17. Campos, N., \& Karanasos, M. (2008). Growth, Volatility and Political Instability: Non-linear Time-series Evidence for Argentina, 18962000. Economics letters, 100, 135-137.

18. Collier, P. (1999). On the Economic Consequences of Civil War. Oxford Economic Papers, 51, 163-83.

19. Del Monte A., \& Papagni, E. (2001). Public Expenditure, Corruption and Economic Growth: the Case of Italy. European Journal of Political Economy, 17(1), 1-16.

20. Diadié, D., \& Lessoua, A. (2013). Natural Resources Exports, Diversification and Economic Growth of CEMAC Countries: On the Impact of Trade with China. African Development Review, 25(2), 189202.

21. Easterly, W. (2001). The Lost Decades: Explaining Developing Countries' Stagnation in Spite of Policy Reform 1980-1998. Journal of Economic Growth, 6(2), 135-157.

22. Easterly, W., \& Levine, R. (1997). Africa's Tragedy: Policies and Ethnic Divisions. Quarterly Journal of Economics, 112(4), 12031250. 
23. Fabro, G., \& Aixalá, J. (2009). Economic Growth and Institutional Quality: Global and Income-Level Analyses. Journal of Economic Issues, 43(4), 997-1023.

24. Fondo S., F., \& Nde T., J. (2012). Governance and Economic Growth in Cameroon. (AERC Research Paper No. 250). Nairobi: African Economic Research Consortium.

25. Fosu, A. K. (2001). Political instability and economic growth in developing economies: some specification empirics. Economic Letters, 70, 289-294.

26. Ghura. D., \& Mercereau, B. (2004). Political Instability and Growth: The Central African Republic (IMF Working Paper No. 80). Washington, D.C: International Monetary Fund.

27. Glaeser, E.T., La Porta, R., Lopez-de-Silanes, F., \& Shleifer, A. (2004). Do Institutions Cause Growth? Journal of Economic Growth, 9(3), 271-303.

28. Grossman, G., \& Helpman, E. (1991). Innovation and Growth in the Global Economy. The MIT Press. Cambridge, Massachusetts.

29. International Monetary Fund (2003). World Economic Outlook. Institutions and Growth. Washington, D.C.: International Monetary Fund.

30. Islam, N. (1995). Growth Empirics: A Panel Data Approach. The Quarterly Journal of Economics, 110(4), 1127-1170.

31. Javaid, J. N., \& Iftikhar, M. N. (2011). What drives the quantity of institutions in the process of growth and development of economy? World Academy of Science, Engineering and Technology, 39, 435-437.

32. Kamgna, S. Y. (2017). Diversification économique en Afrique centrale : Etats des lieux et enseignements at: https://www.researchgate.net/publication/23543958

33. Kapuria-Foreman, V. (1995). Population and Growth Causality in Developing Countries. The Journal of Developing Areas, 29(4), 531540.

34. Kilishi, A. A., Mobolaji, H. I., Yaru, M. A., \& Yakubu, A. T. (2013). Institutions and Economic Performance in Sub-Saharan Africa: A Dynamic Panel Data Analysis. Journal of African Development, 15(2), 91-120.

35. Klomp, J., \& De Haan, J., 2009. Political institutions and economic volatility. European Journal of Political Economy, 25(3), 311-326.

36. Knack, S., \& Keefer, P. (1995). Institutions and economic performance: cross-country tests using alternative institutional measures. Economics and Politics, 7(3), 207- 227. 
37. Levine, R., \& Renelt, D. (1992). A sensitivity Analysis of Crosscountry Growth Regressions. American Economic Review, 82(4), 942963.

38. Lucas, R. (1988). On the Mechanics of Economic Development. Journal of Monetary Economics, 22(1), 3-42.

39. Londregan, J., \& Poole, K. (1990). Poverty, the coup trap, and the seizure of executive power. World Politics, 92, 1-24.

40. Mankiw, G., Romer. D., \& Weil, D. (1992). A Contribution to the Empirics of Economic Growth. The Quarterly Journal of Economics, 107(2), 407-37.

41. Mauro P. (1998). Corruption and the composition of government expenditure. Journal of Public Economics, 69(2), 263-279.

42. Miljkovic, D., \& Rimal, A. (2008). The impact of socio-economic factors on political instability: A cross-country analysis. The Journal of Socio-Economics, 37, 2454-2463.

43. Nasreen, S., Anwar, S., \& Waqar, Q. M. (2015). Institutions, investment and economic growth: a cross-country and panel data study. The Singapore economic review, 60(4), 1-19.

44. North, D. C. (1990). Institutions, Institutional Change, and Economic Performance. New York: Cambridge University Press.

45. North, D. C., \& Weingast, B. R. (1989). Constitutions and Commitment: The Evolution of Institutions Governing Public Choice in Seventeenth-Century England. The Journal of Economic History, 49(4), 803-832.

46. Radu, M. (2015). Political stability - a condition for sustainable growth in Romania? Procedia Economics and Finance, 30, 751 - 757.

47. Rebelo, S. (1991). Long-run policy analysis and long-run growth. Journal of Political Economy, 99(3), 500-521.

48. Rodriguez, F., \& Rodrik, D. (2000). Trade policy and economic growth: A skeptics Guide to the Cross-National Evidence. NBER Macroeconomics Annual, 15, 261-325.

49. Rodrik, D., Subramanian, A., \& Trebbi, F. (2004). Institutions Rule: The Primacy of Institutions Over Geography and Integration in Economic Development. Journal of Economic Growth, 9(2), 131-169.

50. Rodrik, D. (1999). Where did all the growth go? External shocks, Social conflicts, and growth collapses. Journal of Economic Growth, 4(4), 358-412.

51. Romer, P. M. (1990). Capital, labor and productivity, Brookings Papers On Microeconomics, 337-367.

52. Romer. P. M. (1986). Increasing Returns and Long-Run Growth. The Journal of Political Economy, 94(5), 1002-1037. 
53. Scully, G.W. (1989). The size of the state, economic growth and the efficient utilization of national resources. Public Choice, 63(2), 149164.

54. Siermann, C, L, J. (1998). Politics, institutions and economic performance of nations. Books, Edward Elgar Publishing, number 1281.

55. Solow, R. M. (1957). Technical Change and the Aggregate Production function. The Review of Economics and Statistics, 39(3), 312-320.

56. World Bank (2015). World Bank Development Indicators. (Washington D.C.).

57. World Bank (2005). Economic growth in the 1990s: Learning from a decade of reform. Washington, DC 20433: The World Bank.

58. Worldwide Governance Indicators

(2015). httpp://www.worldbank.org/governance/wgi.

59. Yildirim. A., \& Gokalp. M. (2016). Institutions and Economic Performance: A review on the Developing Countries. Procedia Economics and Finance, 38, 347-359.

60. Younis, M., Xiao Lin., L., Sharahili, Y., \& Selvarathinam, S. (2008). Political Stability and Economic Growth in Asia. American Journal of Applied Sciences, 5(3), 203-208.

\section{Appendix}

Table 1: Description of variables and data sources

\begin{tabular}{|l|l|c|}
\hline Variables & Definition & Sources \\
\hline GDP per capita & $\begin{array}{l}\text { The actual GDP per capita in US dollars obtained by } \\
\text { deflating the nominal GDP for all countries. }\end{array}$ & WDI (2015) \\
\hline Active population & Population ages 15-64, total & WDI (2015) \\
\hline Physical capital & Gross capital formation (constant 2010 US\$) & WDI (2015) \\
\hline Human Capital & $\begin{array}{l}\text { School enrolment, secondary (\% gross). This is the ratio of } \\
\text { the total enrolment, regardless of age, and the population of } \\
\text { the age group that officially corresponds to the level of } \\
\text { secondary education. }\end{array}$ & WDI (2015) \\
\hline $\begin{array}{l}\text { Accountability } \\
\text { And }\end{array}$ & $\begin{array}{l}\text { It reflects the perception of the extent to which citizens of a } \\
\text { given country are able to participate in the selection of their } \\
\text { government, as well as freedom of association, freedom of } \\
\text { expression and freedom of Press. }\end{array}$ & WGI (2015) \\
\hline $\begin{array}{l}\text { Political Stability and } \\
\text { Absence of violence } \\
\text { and Terrorism }\end{array}$ & $\begin{array}{l}\text { It is the perception of the likelihood that the current } \\
\text { government will be destabilized by unconstitutional or violent } \\
\text { means, including terrorism. }\end{array}$ & WGI (2015) \\
\hline $\begin{array}{l}\text { Government } \\
\text { Effectiveness }\end{array}$ & $\begin{array}{l}\text { It reflects the perception this indicator provides information of } \\
\text { the quality of public services, the quality of the public service } \\
\text { and its independence from political pressures and the quality } \\
\text { of the formulation and the implementation and the credibility } \\
\text { of the government's commitment. }\end{array}$ & WGI (2015) \\
\hline
\end{tabular}




\begin{tabular}{|l|l|c|}
\hline Regulatory Quality & $\begin{array}{l}\text { It reflects the perception of the ability of the government to } \\
\text { provide sound policies and sound regulations that enable and } \\
\text { promote private sector development }\end{array}$ & WGI (2015) \\
\hline Rule of Law & $\begin{array}{l}\text { It reflects the perception of the extent to which different agents } \\
\text { trust and respect company rules that include the quality of } \\
\text { contract enforcement, property rights, the police and courts } \\
\text { and the likelihood of crime and violence. }\end{array}$ & WGI (2015) \\
\hline Control of Corruption & $\begin{array}{l}\text { It reflects the extent to which the public power is exercised for } \\
\text { private purposes. It encompasses all forms of corruption, } \\
\text { including large and small forms of corruption, as well as the } \\
\text { capture of the state by the elite and private interests. }\end{array}$ & WGI (2015) \\
\hline
\end{tabular}

Source: Author 